Case Study

\title{
ASSESSING AND EMPOWERING COUNSELLING A PATIENT WITH SEVERE DENGUE FEVER ASSOCIATED WITH THROMBOCYTOPENIA
}

\author{
SABISHRUTHI S. ${ }^{1}$, VEDHA PAL JEYAMANI S. ${ }^{*}{ }^{*}$, KAVITHA S. ${ }^{1}$, PONSEGARAN V. ${ }^{1}$, MAGESH M. ${ }^{2}$
}

${ }^{1}$ Department of Pharmacy Practice, Jaya College of Paramedical Sciences, College of Pharmacy, Chennai, India, ${ }^{2}$ Department of Pharmaceutical Chemistry, Jaya College of Paramedical Sciences, College of Pharmacy, Chennai, India

Email: swetha21112000@gmail.com

Received: 02 Apr 2018 Revised and Accepted: 23 Aug 2018

\begin{abstract}
Dengue is one of the common mosquito-borne arbovirus infections, especially in India. Dengue virus is a single strand RNA virus, which composed of four serotypes and these serotypes, belongs to the flavivirus genus. Dengue viruses are normally transmitted through the bites of aedes mosquito species. Dengue is the most frequent cause of fever which is caused with thrombocytopenia. Dengue is probably a fatal ailment that is widely spread through the tropical and subtropical regions of the world affecting urban and semi-urban areas. It also becomes a dominant health concern globally in recent decades. The most serious complications of this infection are dengue haemorrhagic fever and dengue shock syndrome. $18 \mathrm{y}$ old male patient was admitted to the general ward in thiruvallur government hospital with chief complaints of fever, vomiting and dehydration, cough with expectorant for a period of $3 \mathrm{~d}$. The patient was diagnosed with dengue fever followed by thrombocytopenia and advised for proper rehydration therapy. The patient was initiated with prophylactic therapy and Oral Rehydration Solution. He was also treated by focusing points based on patient counselling to recover the current condition. The patient was counseled accordingly as regular sit-ups, with points focusing on disease condition and therapy prescribed. The current case was aimed to target on the counselling points for dengue, which made a better improvement in the patient with severe dengue fever with thrombocytopenia and this could be a measure as community awareness outlook to spread alertness which can avoid the outbreak of Dengue.
\end{abstract}

Keywords: Dengue, Thrombocytopenia, Patient counselling, Awareness

(C) 2018 The Authors. Published by Innovare Academic Sciences Pvt Ltd. This is an open access article under the CC BY license (http://creativecommons.org/licenses/by/4.0/) DOI: http://dx.doi.org/10.22159/ijpps.2018v10i10.26405

\section{INTRODUCTION}

Dengue is a mosquito-borne viral infection, which spreads rapidly $[1,2]$. It is caused by 4 serotypes DENV-dengue virus (DENV1, DENV2, DENV3, and DENV4) Dengue fever, dengue hemorrhagic fever, and dengue shock syndrome; which is one among the lethal illness [3]. This disease leads from a relatively minor febrile illness to a life-threatening condition. Infection is the most common cause of thrombocytopenia. Thrombocytopenia associated with fever helps to narrow the differential diagnosis and management of fever [4]. It also helps to know the various complications of thrombocytopenia and its management. The aedes aegypti mosquitos are the one, which spreads the lethal illness named dengue and dengue viruses are also called as arboviruses [5]. These mosquito breeds in water holding receptacles such as desert coolers, vases, discarded containers, coconut husks, or old tires or in plants close to human dwellings. The accumulation of infection is both man and mosquito [6]. $70 \%$ of the 96 million apparent infections occur in Asia, in which India is making up to one-third of the total. In spite of abundant efforts to control the mosquito populations, dengue fever has arisen, extend and established itself vastly. The most serious complication of the infection is Dengue Hemorrhagic Fever (DHF) and Dengue
Shock Syndrome (DSS). Individuals of all ages and both sexes are susceptible to dengue fever [7]. It is accompanied by high fever, headache, dehydration, anorexia, muscle and joint pain, etc. Some patients also have a macular rash, lymphadenopathy, and palatal vesicles. Epistaxis and scattered petechiae are commonly seen in uncomplicated dengue. Preexisting gastrointestinal lesions may bleed during the acute illness $[8,9]$. It can be treated with antibiotics, painkillers and oral fluids. Each year between 50 and 528 million people are infected, and fatality reports were approximately 10,000 to 20,000 are reported due to lack of a simple tool to differentiate mild life-threatening infection. This may lead to unnecessary hospitalization to dengue patients [10].

\section{CASE REPORT}

$18 \mathrm{y}$ old male patient was admitted in the male general male ward in Thiruvallur government hospital with chief complaints of fever, vomiting, and dehydration for $3 \mathrm{~d}$ and cough with expectorant for a period of $3 \mathrm{~d}$. On general examination, the patient was conscious, oriented, and febrile. On examination, patient Blood pressure was found deceased. The abdomen evaluation revealed that per abdomen was soft, and other observed parameters are normal.

Table 1: Symptoms of dengue

\begin{tabular}{lll}
\hline S. No. & Symptoms & Patient condition \\
\hline 1. & Loose stools & + \\
2. & Fever & + \\
3. & Vomiting & - \\
4. & Melena & + \\
5. & Dehydration & - \\
6. & Abdominal Pain & + \\
7. & Muscle and joint pain & + \\
8. & A cough with expectorant & + \\
9. & Headache & \\
\hline
\end{tabular}

${ }^{*}+$ and-denotes positive and negative of symptoms with accordance with particular symptoms of Dengue. 
Table 2: Laboratorical investigations from the day of admission

\begin{tabular}{|c|c|c|c|c|c|c|c|c|c|c|}
\hline $\begin{array}{l}\text { S. } \\
\text { No. }\end{array}$ & Lab parameters & Units & $\begin{array}{l}\text { Day 1* } \\
\text { (morn) }\end{array}$ & $\begin{array}{l}\text { Day } 1 \\
\text { (eve) }\end{array}$ & $\begin{array}{l}\text { Day } 2 \\
\text { (morn) }\end{array}$ & $\begin{array}{l}\text { Day } 2 \\
\text { (aft) }\end{array}$ & $\begin{array}{l}\text { Day } 2 \\
\text { (eve) }\end{array}$ & $\begin{array}{l}\text { Day } 3 \\
\text { (morn) }\end{array}$ & $\begin{array}{l}\text { Day } 3 \\
\text { (aft) }\end{array}$ & $\begin{array}{l}\text { Day } 3 \\
\text { (eve) }\end{array}$ \\
\hline 1. & White blood count (WBC) & $10^{3} / \mu \mathrm{l}$ & 4800 & 3800 & 3500 & 2900 & 2900 & 4100 & 3100 & 5600 \\
\hline 2. & Red blood count (RBC) & $10^{6} / \mu \mathrm{l}$ & 4.79 & 3.86 & 4.56 & 4.37 & - & - & 3.76 & - \\
\hline 3. & Haematocrit (HCT) & $\%$ & 41.2 & 34.6 & 39.3 & 38.3 & - & - & 36.8 & - \\
\hline 4. & Haemoglobin (HB) & $\mathrm{g} / \mathrm{dL}$ & 13 & 11.5 & 13.9 & 13.5 & 12.6 & 15.3 & 12.6 & 15.8 \\
\hline 5. & $\begin{array}{l}\text { Mean corpuscular volume } \\
(\mathrm{MCV})\end{array}$ & $\mathrm{fL}$ & 86.0 & 89.6 & 86.2 & 87.6 & - & - & 85.3 & - \\
\hline 6. & $\begin{array}{l}\text { Mean cell haemoglobin } \\
(\mathrm{MCH})\end{array}$ & $\mathrm{Pg}$ & 30.5 & 29.8 & 30.5 & 30.9 & - & - & 28.7 & - \\
\hline 7. & $\begin{array}{l}\text { Mean cell haemoglobin } \\
\text { concentration (MCHC) }\end{array}$ & $\mathrm{g} / \mathrm{dL}$ & 35.4 & 33.2 & 35.4 & 35.2 & - & - & 34.5 & - \\
\hline 8. & Platelets (PLT) & $10^{3} / \mu \mathrm{l}$ & 80000 & 79000 & 78000 & 71000 & 69000 & 67000 & 50000 & 46000 \\
\hline 9. & Lymphocyte & $10^{3} / \mu \mathrm{l}$ & 0.9 & 0.6 & 0.6 & 0.8 & - & - & 0.6 & - \\
\hline 10. & Lymphocyte \% & $\%$ & 30.7 & 14.5 & 18.4 & 27.6 & - & - & 14.7 & - \\
\hline 11. & RDW-SD & $\mathrm{fL}$ & 45.1 & 46.5 & 45.9 & 45.7 & - & - & 44.1 & - \\
\hline 12. & $\mathrm{RDW}-\mathrm{CV}$ & $\%$ & 13.6 & 13.3 & 13.8 & 13.4 & - & - & 13.2 & - \\
\hline 13. & $\begin{array}{l}\text { Platelet distribution width } \\
\text { (PDW) }\end{array}$ & $\mathrm{fL}$ & 13.1 & 11.7 & 14.5 & 17.0 & - & - & 11.8 & - \\
\hline 14. & $\begin{array}{l}\text { Mean platelet volume } \\
\text { (MPV) }\end{array}$ & $\mathrm{fL}$ & 11.1 & 10.6 & 11.0 & 12.7 & - & - & 10.4 & - \\
\hline 15. & $\begin{array}{l}\text { Platelet large cell ratio } \\
\text { (PCR) }\end{array}$ & $\%$ & 32.1 & 28.1 & 34.5 & +45.2 & - & - & 38.2 & - \\
\hline 16. & Procalcitonin & $\%$ & -0.10 & -0.11 & -0.11 & -0.12 & - & - & -0.11 & - \\
\hline 17. & Packed cell volume (PCV) & $\%$ & 38.6 & 34.6 & 39.3 & 38.3 & 37.7 & 43 & 31 & 44 \\
\hline 18. & Mixed cell count & $10^{3} / \mu \mathrm{l}$ & 0.4 & 0.2 & 0.3 & - & - & - & - & - \\
\hline 19. & Mixed cell count $\%$ & $\%$ & 10.6 & 5.2 & 9.2 & - & - & - & - & - \\
\hline 20. & Neutrophil count & $10^{3} / \mu \mathrm{l}$ & 2.3 & 3.0 & 2.6 & - & - & - & - & - \\
\hline 21. & Neutrophil count $\%$ & $\%$ & 58.7 & 80.3 & 72.4 & - & - & - & - & - \\
\hline
\end{tabular}

*Day of admission, RDW-SD represents Red blood cell Distribution Width of actual size, RDW-CV represents Red blood cell Distribution Width of cell volume, pg represents picograms, fL represents femtolitres, $\mu$ represents microliters, $d L$ represents decilitres, g represents grams.

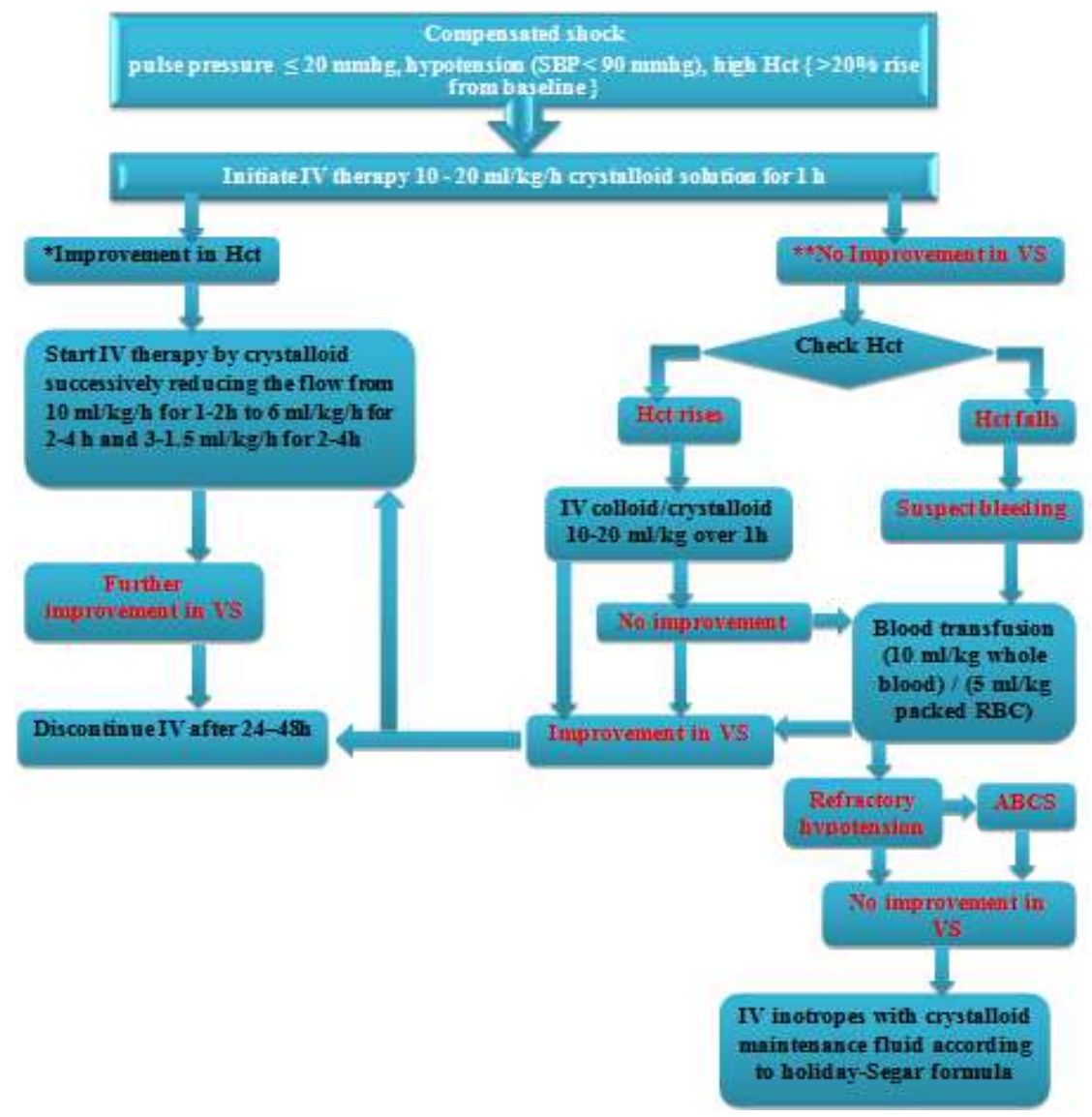

Fig. 1: Volume replacement algorithm for patients with moderate dengue fever (DHF grade I, II \& III), ABCS = Acidosis, Bleeding, Calcium (Na++and $\mathrm{K+}$ ), Sugar, SBP-systolic blood pressure, IV-Intravenous, ${ }^{*}$ Improvement: Hct falls, pulse rate and Blood pressure stable, Urine output rises, ${ }^{* *}$ No improvement: Hct or pulse rate rises, pulse pressure falls below: 20 mmh, urine output falls 


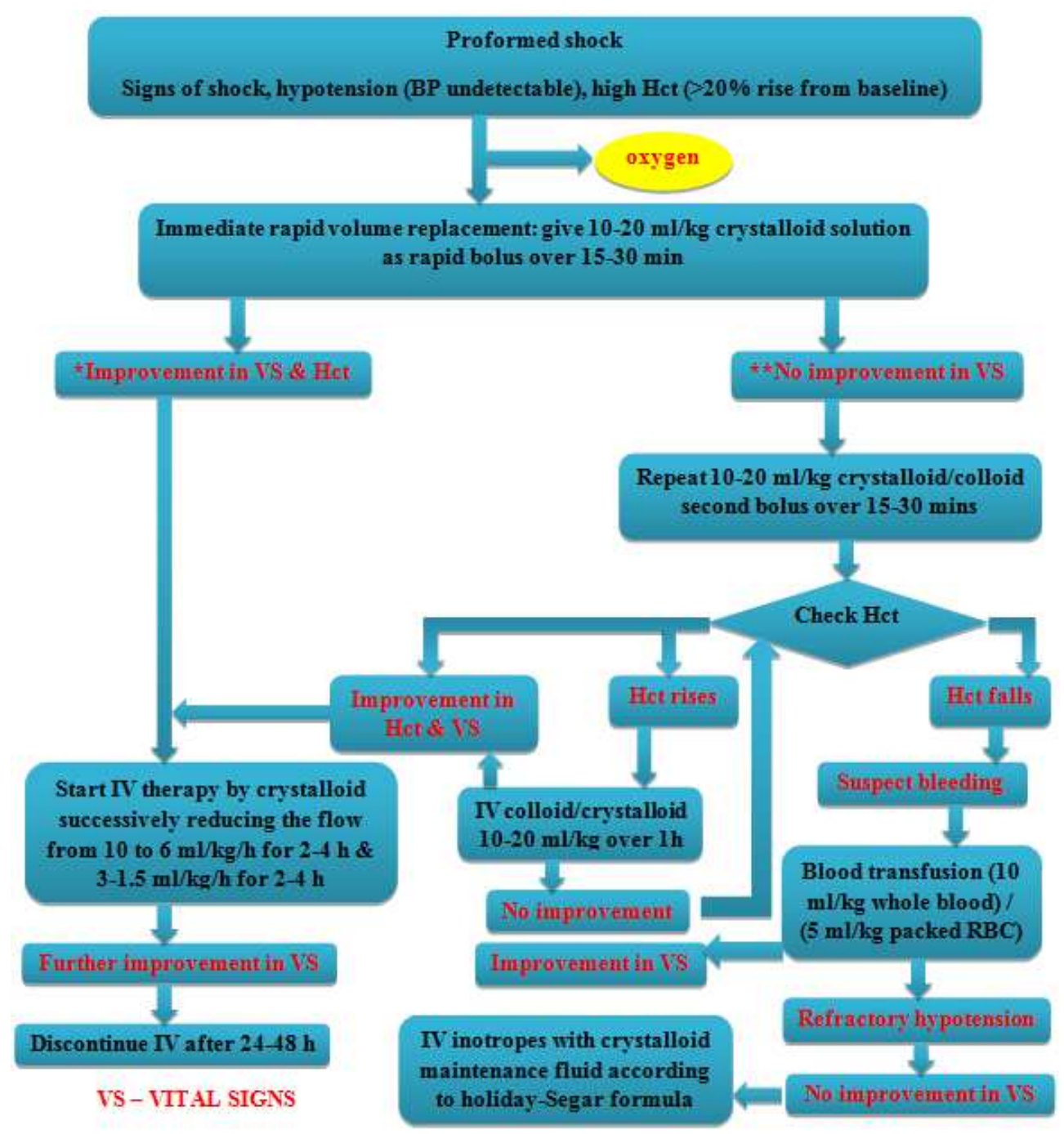

Fig. 2: Volume replacement algorithm for patients with severe dengue fever [DHF IV (DSS)]

\section{DISCUSSION}

The patient was observed with a low platelet count, low white blood count, packed cell volume and Mean cell haemoglobin concentration at the time of admission. The patient haematology and biochemical parameters were observed at regular intervals. The serological findings such as Immunoglobulin $\mathrm{M}$ and Immunoglobulin $\mathrm{G}$ were found positive, which indicated the presence of Dengue. The patient was diagnosed with dengue fever and advised for proper rehydration therapy. The patient was treated with Injection Cefotaxime $1 \mathrm{~g}$ twice a day, Injection Ranitidine 2CC twice a day, Injection Paracetamol twice a day if necessary, Tabet Chlorpheniramine $4 \mathrm{mg}$ twice a day, Tabet Vitamin B Complex, Tab. Paracetamol, Tab. Rantac, Platelet oral fluids and Oral Rehydration Solution as prophylactic therapy.

The patient was counselled accordingly as regular sit-ups, with points focusing disease condition, therapy prescribed. The patient counselling points include lifestyle changes along with dietary restrictions.

- Avoid mosquito bites when traveling in tropical areas by using powerful plug-in mosquito repellent, even indoors as aedes is day bitting mosquito.

- Breeding of vector mosquitoes can be reduced by eliminating small accumulations of stagnant water around human habitats.

- Eliminating mosquito breeding sites in these areas is another key prevention measure. Stay away from old tires, cans, or flower pots that collect rain. Coolers and tanks must regularly be cleaned and kerosene oil added to their water. Because these are the ideal places for mosquitoes to breed.

- It is a safer bet to use mosquito nets while sleeping, which was a common practice. Mosquito bats are also advisable.

- Oral fluids should be encoursed to drink throughout the day, oral dehydration solution, fruit juice to prevent dehydration from fever, lack of oral intake or vomiting. Drinking fresh Vitamin $\mathrm{C}$ juice will boost up the digestion as well as it will promote the antibodies for a rapid recovery.

- Drink plenty of water to flush out the toxins from the body, which excreted in the form of urine.

- Patients are advisable to consume more green leafy vegetables, proteins and minerals in order to boost up immunity against dengue virus.

- Patients are advised to avoid oily and spicy food. Because it may aggravate the patient condition.

- Make sure window and door screens are secure and free of holes. It helps, as well, to get rid of places where mosquitoes may breed.

- Regularly change the water in outdoor birdbaths and pets' water dishes.

- Prevention techniques can be pursued on preventing mosquito bites when traveling to areas where dengue occurs. Dengue might occur where there is low sanitation. 
- If someone in the home gets dengue fever, vigilant efforts should be exerted to protect other family members from mosquitoes.

- When outdoors, wear long-sleeved shirts and long pants tucked into socks. When indoors, use air conditioning if available. Stay away from heavily populated residential areas.

- Maintain good hygiene at home and environment, which are very essential. Cleanliness, a healthy immune system, and a proper diet will keep you away from dengue.

- Make an effort to check whether the doors and windows are shut properly, especially during the evenings. Bed rest is recommended for symptomatic dengue fever.

- Light camphor inside your home and apply neem oil all over your body to keep away mosquitoes [11-15].

\section{CONCLUSION}

Dengue fever most commonly affects young adults, mostly males. Hence, dengue fever does not have any particular medical remedy; the clinically improve the monitoring is broadly dependent on hematological complications. The only way to prevent us from dengue fever is preventing us from a mosquito bit. However, if caught early on, it is easier to prevent complications. The current case was planned to target on the counselling points for dengue, which made a better improvement in the patient and we take this measure as a community awareness outlook to spread alertness which can avoid the outbreak of Dengue.

\section{ACKNOWLEDGMENT}

The authors are thankful to Dr. C. Sekar, Chief Medical Superintendent, Government hospital, Thiruvallur for his constant support and encouragement throughout the study. We thank the patients who gave their willing consent for the publication of their case by sharing complete information needed for the study.

\section{COMPLIANCE WITH ETHICAL STANDARDS}

Written informed consent was obtained from the patient for publication of the case study, the inclusion of the accompanying images. Copies of written consent may be requested for review from the corresponding author.

\section{CONFLICT OF INTRESTS}

The authors declare no conflicts of interest concerning the content of this case report.

\section{REFERENCES}

1. Tamibmaniam J, Hussin N, Cheah WK. Proposal of a clinical decision tree algorithm using factors associated with severe dengue infection. PLoS ONE 2016;11:1-10.

2. Medagoda K, Gunathilaka SB, De Silva HJ. A case of self-limiting coombs' negative hemolytic anemia following dengue shock syndrome. Ceylon Med 2003;48:147-8.

3. Verma R, Jatav VK, Sharma S. Identification of inhibitors of dengue virus (DENV1, DENV2 AND DENV3) NS2B/NS3 serine protease: a molicular docking and simulation approach. Asian J Pharm Clin Res 2015;8:287-92.

4. Whitehorn J, Farrar J. Dengue. Br Med Bul 1995;95:161-73.

5. Khan DM, Kuppusamy K, Sumathi S, Mrinalini VR. Evaluation of thrombocytopenia in dengue infection along with seasonal variation in rural melmaruvathur. J Clin Diagn Res 2014; 8:39-42.

6. Garg S, Arora R, Kakkar N. Fever and petechiae in a middle aged male. Labmedicine 2007;38:23-5.

7. Tayade MR, Shinkar DM, Patil PB, Saudagar RB. Emerging therapy for dengue. Int J Curr Pharm Res 2018;10:1-4.

8. Kulkarn D, Sharma B. Dengue fever-induced cold-agglutinin syndrome. Ther Adv Infect Dis 2014;2:97-9.

9. Dutta D, Kuila P, Chatterjee D, Das S. Co-infection of brucella and dengue virus. Asian J Pharm Clin Res 2017;10:299-301.

10. Aroor AR, Saya RP, Sharma A, Venkatesh A, Alva R. Clinical manifestations and predictors of thrombocytopenia in hospitalized adults with dengue fever. N Am J Med Sci 2015;7:547-52.

11. Radakovic S, Graninger W, Müller C, Hönigsmann H, Tanew A. Dengue hemorrhagic fever in a British travel guide. J Am Acad Dermatol 2002;46:430-3.

12. Liao B, Tang Y. Serum levels of soluble vascular cell adhesion molecules may correlate with the severity of dengue virus infection in adults. Emer Microbes Infect 2015;4:e24.

13. Gupta MK, Shrivastava AK, Chauhan APS, Gaur DS, Mishra KK, Sharma S. Comparative study of the shiva guggulu and simhanada guggulu in the management of amavata (rheumatoid arthritis). Int J Appl Pharm 2016;8:5-12.

14. Farista R, Muragundi PM. Practical possibilities to empower patients in the management of inflammatory bowel disease. J Crit Rev 2016;3:1-5.

15. Harikesh Maurya $H$, Tirath Kumar $T$. A review on comprehensive overview in the management of nephrotic disorders. J Crit Rev 2016;3:34-43. 